\title{
90-lecie powstania Komitet Daru Narodowego dla Marii Skłodowskiej-Curie
}

W dniu 29 stycznia 2014 roku w gmachu dawnego Instytutu Onkologii przy ul. Wawelskiej odbyła sie uroczystość upamiętniająca 90. rocznicę powstania Komitetu Daru Narodowego dla Marii Skłodowskiej-Curie. Darem tym, zgod-

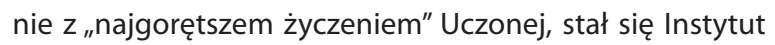
Radowy w Warszawie.

Komitet Polskiego Daru Narodowego powstał w odpowiedzi na uroczystości 25-lecia odkrycia radu, obchodzone we Francji w grudniu 1923 roku z udziałem elit francuskiej nauki i polityki, z Prezydentem Republiki Alexandre Millerandem na czele. Francja, decyzją Izby Deputowanych, ofiarowała wówczas Uczonej swój Dar Narodowy w postaci dożywotniej pensji. Było to niezwykle rzadkie wyróżnienie - wcześniej otrzymali je m.in. Louis Jacques Daguerre (w 1839 roku - twórca dagerotypu, a tym samym — początków fotografii) i Ludwik Pasteur (w 1874).

Inicjatorem Polskiego Daru Narodowego był Polski Komitet do Zwalczania Raka, który już w grudniu 1923 roku ogłosił apel o powszechną zbiórkę funduszy na budowę Instytutu Radowego. Organizatorem zbiórki stał się następnie Komitet Polskiego Daru Narodowego, tworzony w pierwszych miesiącach 1924 roku. Honorową Prezesurę Komitetu przyjął Prezydent Rzeczypospolitej Stanisław Wojciechowski, przewodniczącym Zarządu został Marszałek Senatu Wojciech Trąmpczyński, a jego zastępcą — Marszałek Sejmu Maciej Rataj. Członkostwo w Komitecie zadeklarowali m.in. wszyscy ministrowie Gabinetu Premiera Władysława Grabskiego oraz przedstawiciele uniwersytetów i towarzystw naukowych.

Podczas obecnej uroczystości w holu budynku przy ul. Wawelskiej odsłonięto tablicę pamiątkową przypominającą o wielkiej ofiarności społeczeństwa polskiego na rzecz walki z rakiem. Wyrazem tej ofiarności był przede wszystkim masowy odzew na apel Polskiego Komitetu do Zwalczania Raka w latach 1924-1932, walnie wspomagający budowę Instytutu Radowego, ale też ogólnopolska zbiórka na rzecz Narodowego Programu Zwalczania Chorób Nowotworowych, organizowana w 1998 r. przez Polską Fundację Europejskiej Szkoły Onkologii, z której część funduszy wsparła obecną modernizację historycznego budynku przy ul. Wawelskiej.

Odsłonięcia tablicy dokonali: dr Bartosz Arłukowicz - Minister Zdrowia, prof. Andrzej Kułakowski - nestor

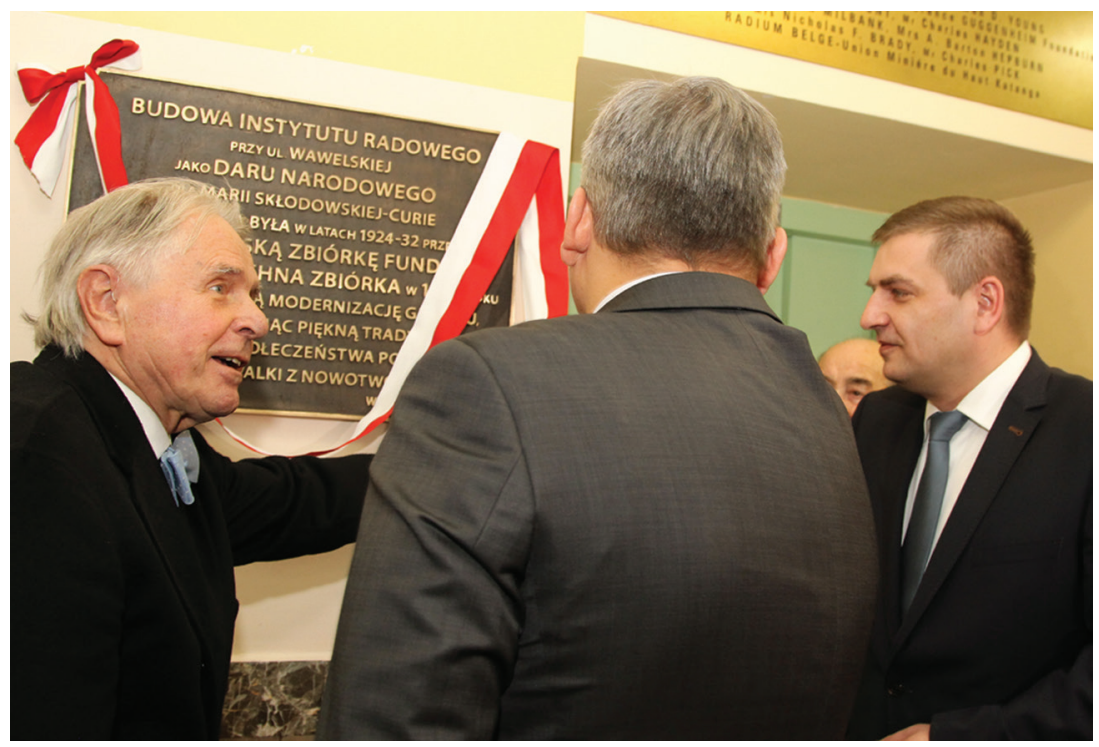

Prof. Jerzy Woy-Wojciechowski, prof. Krzysztof Warzocha, prof. Andrzej Kułakowski i dr Bartosz Arłukowicz dokonują odsłonięcia pamiątkowej tablicy w gmachu przy ul. Wawelskiej Fot. Sławomir Mazur 


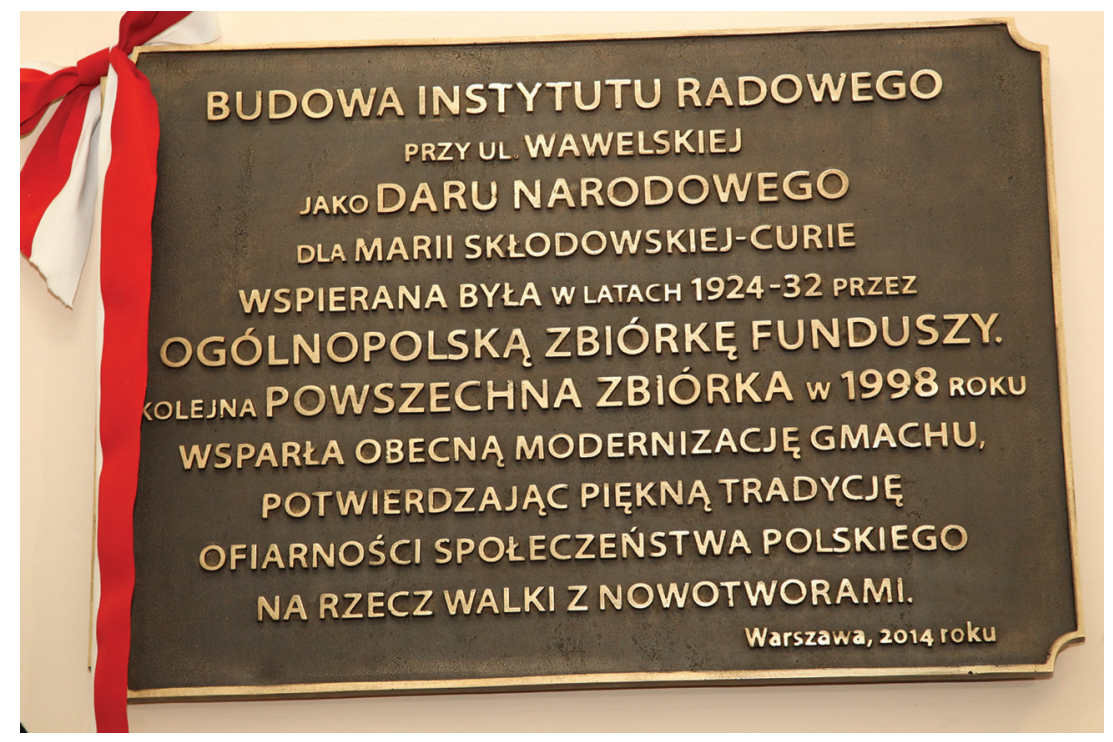

Fot. Sławomir Mazur

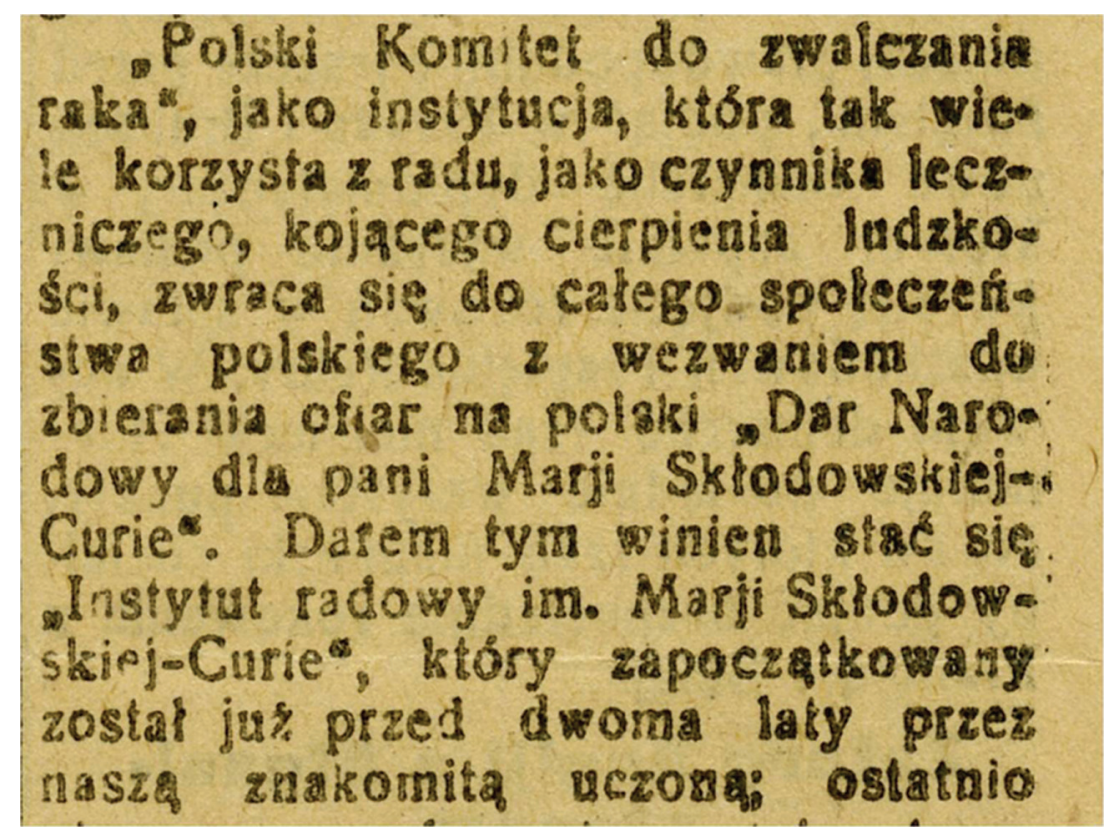

Apel Polskiego Komitetu do Zwalczania Raka zamieszczony w prasie codziennej w grudniu 1923 r.

warszawskiej i polskiej onkologii, prof. Krzysztof Warzocha — Dyrektor Centrum Onkologii — Instytutu im. Marii Skłodowskiej-Curie, i prof. Jerzy Woy-Wojciechowski — Prezes Polskiego Towarzystwa Lekarskiego oraz Fundacji im. Jakuba hr. Potockiego.
Następnie zebrani udali się do sali im. prof. Józefa Laskowskiego na sesję naukowo-historyczną, podczas której prof. Edward Towpik przedstawił genezę i historię Komitetu Daru Narodowego dla Marii Skłodowskiej-Curie, a prof. Andrzej Kułakowski podzielił się wspomnieniami 


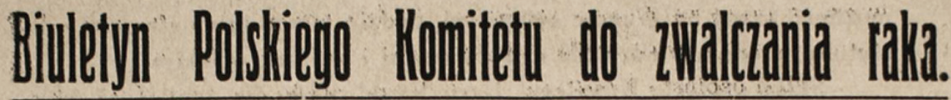

25-LECIE ODKRYCLA RADU (RADIUM) I „POLSKI DAR NARODOWY DLA MARJI SKLODOWSKIEJ-CURIE".

26 grudnia r. ub. w Sorbonie obchodzono w sposób niezwykle uroczysty 25-letnią rocznice odkrycia radu przez p. Skłodowską-Curie i jej męża, p. Curie. Prezydent Rzeczypospolitej francuskiej, ministrowie, setki naukowych stowarzyszeń francuskich i obcych składały Czcigodnej Jubilatce wyrazy najgłębszego hołdu. Polski Komitet do zwalczania raka również wysłał telegram hołdowniczy i zajął się sprawa wysłania odpowiednich depesz przez szereg instytucji państwowych (Sejm, Senat), oraz naukowych (Uniwersytet Warszawski, Akademja Lekarska, Warsz. Tow. Lekarskie i w. in.). W ten sposób nie zabrakło dowodów uznania i z Ojczyzny. Wobec zaś faktu, że Francja w dniu tym ofianowała znakomitej Uczonej "dar narodowy", Polski komitet do zwalczania raka wystapił z projektem utworzenia "Polskiego daru narodowego" i ogłosił we wszystkich pismach dnia 24.XII 1923 r. następującą odezwę:

Informacja o inicjatywie polskiego Daru Narodowego dla Marii Skłodowskiej-Curie, zamieszczona w Biuletynie Polskiego Komitetu do Zwalczania Raka, który powołany został do życia jako periodyk PKdZR zaledwie kilka miesięcy wcześniej

z ogólnopolskiej zbiórki przeprowadzonej w 1998 roku. Prof. Krzysztof Warzocha zaprezentował genezę wielospecjalistycznych centrów onkologii (comprehensive cancer centers) jako optymalnego miejsca leczenia nowotworów oraz przedstawił dzień dzisiejszy i perspektywy Centrum
Onkologii - Instytutu im. Marii Skłodowskiej-Curie, zaś prof. Piotr Wysocki, który niemal w przeddzień wygrał konkurs na stanowisko kierownika Kliniki Onkologicznej przy ul. Wawelskiej zaprezentował swoją wizję rozwoju tej placówki.

Prof. Edward Towpik

Redakcja Naukowa CO-I 